\title{
Democracy, Conscription, and War: The Effects of Political Regimes and Types of Military Recruiting on the Initiation of Militarized Interstate Disputes*
}

\author{
Susumu Annaka†; Munenori Kita ; Naonari Yajima\$; Rui Asano**
}

\begin{abstract}
This paper presents an analysis of the impact of political regimes and type of military recruitment on the probability of the occurrence of international conflicts. In the last few years, the (re) introduction of military conscription has been a focus of public debate, but empirical analysis of the issue remains limited. We argue that democratic nations with conscription-based military recruitment in place are less likely to initiate international conflicts than those with voluntary recruitment because public opinion will estimate a higher probability of direct involvement in disputes, causing political leaders to refrain from conflicts, even though stable military resources are in place. On the other hand, authoritarian nations with conscription-based recruitment systems are more likely to engage in conflicts than those with voluntary recruitment systems because political leaders are not accountable to the people, even though the cost of war is calculated in the same manner as that in democratic nations. To test this reasoning, we use directeddyadic data from 1816 to 2005. Our analysis strongly supports our theoretical expectations.
\end{abstract}

* The previous version of this paper was presented at the 2019 annual meeting of the Japan Association for Comparative Politics. We wish to express our gratitude to Ikuo Kume, Masaru Kohno, Atsushi Ishida, Noriyo Isozaki, Hiroyuki Hoshiro, and Gento Kato for their comments.

$\dagger$ Assistant Professor at Waseda Institute of Advanced Studies, Waseda University

E-mail annaka@aoni.waseda.jp

\# Ph.D candidate at Graduate School of Political Science, Waseda University

$\S$ Research Associate at Waseda Institute of Political Economy, Waseda University

** Ph.D candidate at Graduate School of Political Science, Waseda University 


\section{Introduction}

The perception that countries with conscription-based military recruitment systems are aggressive toward neighboring countries may have arisen from the aggression of countries with conscription during WW II and in later periods countries such as North Korea with its aggressive military practices. Choi and James (2003) and Pickering (2011) found that conscription leads a country to engage in militarized international disputes (MIDs). Their research implies that the different types of military recruitment volunteer and conscription—have a great impact on a country's military aggressiveness.

Many international relations scholars regard democracy as one of the most important factors affecting a country's attitude toward neighboring countries (Maoz and Russet 1993; Oneal and Russet 1999; Schultz 2001). They state that democratic countries tend to be more pacifistic toward one another, and this line of research based on the democratic peace (DP) theory, analyzes the relationship between political regimes and international conflicts. However, DP does not consider domestic factors, such as military recruitment type, which we propose to be of paramount importance.

A number of studies have attempted to explore the effect of conscription on international conflicts conditioned by political regimes. For instance, Vasquez (2005) 
argues that the numbers of citizens who die in conflict is lower in democracies with military conscription. In contrast, Horowitz, Simpson, and Stam (2011) report that the number of citizens who die in conflict is lower in democracies with voluntary military service. These conclusions contradict each other, and both studies analyze the factors affecting higher numbers of casualties in international conflicts, considering the relationship between political regimes and military recruitment type. However, their research does not necessarily pay much attention to how these cause a country to be more or less aggressive toward other countries instead of casualties. The current study tackles this issue by analyzing a directed-dyadic dataset spanning 1816 to 2005 .

This paper is organized as follows. Section 2 presents a literature review on the topic. In section 3, we explain our theoretical framework and hypotheses. In section 4, we conduct statistical analyses of our hypotheses. Finally, section 5 is our conclusion based on our results and suggest directions for future studies. 


\section{Literature review}

\subsection{Democracy and war}

The Democratic Peace theory (hereinafter DP) is the theory that democracies do not start wars with each other, which was introduced by Emmanuel Kant's Perpetual Peace. He argues that citizens of republican nations, interpreted as democracy in modern contexts, will never support war [1795]. In contemporary political science, the theoretical framework for DP is thought to have originated with Doyle (1983a, 1983b, 1986). The empirical study of DP has truly begun following the work of authors such as Maoz and Abdolali (1989), Bremer (1992, 1993) and Maoz and Russet (1993). Many empirical studies have shown that democratic nations rarely start wars with other democracies (dyadic level), while several empirical studies provide evidence that democratic nations do not tend to start wars (monadic level) ${ }^{1}$.

It can be noted that a number of studies have supported DP at the dyadic level

1 According to Gleditsch and Hegre (1997), DP can be applied at three different levels: (1) in the study of nation states (monadic level), (2) in the study of relationships between states (dyadic level), and (3) in the study of international political systems (international level). However, they imply that there is little research on DP at the international level. Then, we focus on DP at the monadic and dyadic level in this article. 
(e.g., Beck, Katz, and Tucker 1998; Ray 1998; Gartzke 1998, 2000; Bueno de Mesquita et al. 1999; Oneal and Russet 1999; Oneal, Russet, and Berbaum 2003; Schultz 2001; Hensel, Goertz, and Diehl 2000; Dafoe 2011; Goldsmith et al. 2017). Furthermore, studies such as those conducted by Fearon (1994) and Schultz (2001) have also provided evidence for DP by revealing the conditions under which wars start by studying factors with a rational model. Johns and Davies (2012) and Tomz and Weeks (2013) also show through the survey experiments that people in democratic countries are more likely to hesitate to attack other democratic countries than authoritarian ones.

In contrast to the studies of DP at the dyadic level, there is no strong evidence to support DP at the monadic level (Benoit 1996). For example, Mansfield and Snyder $(1995,2002)$ argue that, especially when in the democratization phase, nations tend to develop a stronger pro-war sentiment. On the other hands, Benoit (1996) suggests that democratic peace not only exists between different democratic states, but that the establishment of democracy makes a country less likely to cause a war. Rummel (1995), Rousseau et al. (1996), Enterline (1998), and Ward and Gleditsch (1998) also support DP at the monadic level.

The overview of the studies of DP at these two levels implies that DP is strongly 
confirmed at the dyadic level, while not necessarily at the monadic level. One plausible reason is that other domestic factors also affect the aggressivity of a democratic country at the monadic level. Among them we focus on military recruitment system because it is directly related to military operations without a doubt.

\subsection{Military recruitment types and war}

Regarding the relationship between conscription and international conflicts, several researches show that states with conscription are indeed more likely to start conflicts.

Choi and James (2003) analyze conflict data between 1882 and 1992 and find that nations with conscription are more likely to get involved in military interstate disputes (MIDs). Pickering (2011) studies conflicts between 1946 and 2001, using time series cross-section data, and reports that states with conscription has a higher probability of participating in international military intervention (IMI) missions.

Another study by Choi and James (2008) utilize dyadic data spanning 1950 through 1992, and find that conscription actually has a restraining effect on a nation's involvement in conflict, which contradicts their results of 2003 study. Results from 
studies such as those conducted by Horowitz and Levendusky (2011) and Kriner and Shen (2016) indicate that the introduction of conscription leads to lower public support for a nation's involvement in conflict, based on their experimental surveys.

There is limited previous research that explores an effect of conscription on the probability of a state becoming involved in foreign conflict. There seems to be no academic consensus arguing that conscription leads to greater pro-war sentiment.

\subsection{Interaction between political regimes and military recruitment types}

The abovementioned literature treats political systems and military recruitment as two different entities. However, there may be the interaction effects between these two factors on international disputes. Vasquez (2005) utilizes conflict data between 1950 and 1985 and finds that democratic countries with conscription incur fewer casualties in conflicts. On the other hand, Horowitz, Simpson, and Stam (2011) study conflicts between 1816 and 2001 and report that democracies with voluntary military service incur fewer casualties in conflicts. Further investigation is needed to reconcile these mixed results. 
Their analyses pay much attention to the monadic types of political regime variables only. When a country's military aggressiveness is analyzed, however, DP at the dyadic level should be considered as a lot of previous literature suggest. Therefore, we take these issues into consideration by using directed dyad data, including the political system types of both the offender and defender sides, and the military recruitment types of the offender side.

\section{Theoretical framework and hypotheses}

Previous research on whether conscription increases the probability of the initiation of an armed conflict has reported, using observational data, that there is higher risk with conscription (Choi and James 2003; Pickering 2011). The theoretical basis for this is that Conscripted soldiers can be stably deployed immediately if needed. On the other hand, voluntary soldiers may be too small in number for initiating military disputes (Choi and James 2003). Nonetheless, experimental research has shown that conscription leads to lower public support for participation in conflicts (Horowitz and Levendusky 2011; Kriner and Shen 2016). This means that, as opposed to countries with voluntary 
recruitment, voters in countries with conscription-based recruitment feel there is a higher chance that they or their own relatives might be involved in an armed conflict, causing voters in these countries to be more cautious about going to war.

In this sense, previous research investigating whether conscription leads to conflict uses different types of data to arrive at opposing conclusions. In other words, studies that have shown that conscription leads to a higher probability of involvement in a conflict seem to focus mainly on the behavior of political leaders, while studies that have shown that conscription leads to lower public support for war seem to focus mainly on public opinion. Therefore, a consistent theory for these different actors must be developed.

From the perspective of voters, a conscription system moderately increases the feeling that they or their own relatives might have to directly participate in war, meaning that people in countries with conscription will be more cautious about initiating conflict compared to countries with voluntary recruitment, where soldiers are usually in the armed forces because of their passion or economic factors. Vasquez (2005) argues that "this military element of Kantian theory is important because it influences the degree to which the costs of going to war would be shouldered by a large or narrow sector of 
democratic society" (851). Previous research has also indicated that this is the pattern.

The idea that voter preferences influence the behaviors of political leaders is an established precept in the study of democracies (Bueno de Mesquita et al. 1999). It stands to reason that if political leaders have to be attentive to public preferences, countries with conscription should be less likely to become involved in conflicts than countries with voluntary recruitment.

However, this is unlikely to be the case in authoritarian regimes, where conscription allows political elites to maintain a strong military presence, and they can manipulate the media that underestimate the costs of war. It is probable that conscription increases the likelihood of involvement in disputes in these regimes, even though anti-war sentiment might exist in the population, as the decisions made by political elites do not necessarily reflect the opinions of the general population. Therefore, we predict that authoritarian regimes with conscription will have a higher probability of involvement in conflict than those with voluntary recruitment. We compile the following two testable hypotheses based upon these theoretical reasonings: 
Hypothesis 1: Democratic governments are less likely to initiate international conflicts when they have conscription-based military recruitment than when they have a volunteer-based military recruitment.

Hypothesis 2: Authoritarian governments are more likely to initiate international conflicts when they have conscription-based military recruitment than when they have a volunteer-based military recruitment.

\section{Research design}

Our unit of analysis is a directed dyad of two countries. One side is a potential offender, and the other side is a potential defender. This allows us to investigate the combination of the political regime types of potential war participants. Our dataset, compiled with EUGene (Bennet and Stam 2000), covers the time span from 1816 to $2005^{2}$.

2 The countries in the dataset are included for the following criteria. "(1) prior to 1920 , the entity must have had a population greater than 500,000 and have had diplomatic missions at or above the rank of charge d'affaires with Britain and France. (2) after 1920, the entity must be a member of the League of Nations or the United Nations, or have a population greater than 500,000 and receive diplomatic missions from two major powers." (Correlates of War Project 2017: 5) 


\subsection{Key explanatory variables}

We use two sets of key explanatory variables. One set contains the variables of the military recruitment systems of potential offenders and defenders. The data are sourced from the Military Recruitment Dataset version 2014, compiled by Toronto (2014). This dataset covers countries' types of military recruitment from 1800 to 2005 . Each variable used in our analysis, whether for an offender or a defender, is a dummy variable; each variable is coded one if a country adopts conscription in a given year and zero if a country adopts voluntary recruitment.

The other dataset contains the variables of the political regime types of potential offenders and defenders. The Polity IV dataset (Marshall and Jaggers 2002) codes democracy level from -10 (most autocratic) to 10 (most democratic). Each variable of political regime type of an offender or a defender is a dummy variable, coded one if its polity score is more than or equal to 6 .

Using these two sets of key explanatory variables, we include interaction terms between military recruitment types and political regime types for potential offenders and defenders. We include an interaction term between political regime variables for both 
potential offenders and defenders to control for democratic peace at the dyadic level.

\subsection{Dependent variable and model}

We use MIDs as our dependent variable. An MID is defined as "a sharp disagreement or collision in interests between two or more actors" (Jones et al. 1996: 168). We choose MIDs rather than casualty numbers as our dependent variable because casualty numbers are not only affected by a country's military aggressiveness but also other factors such as the differences of discipline and order between professional armies and conscript armies. The choice of MIDs as the dependent variable allows us to clearly analyze the factor of pro-war sentiment. The latest edition of the dataset includes MIDs between 1816 and 2010 (Maoz et al. 2019). Our dependent variables are dichotomous and coded one for a year when an offender initiates a war against a defender. We use logistic regressions because our dependent variable is dichotomous.

\subsection{Control variables}


Our control variables are chosen based on the research of Goldsmith et al. (2017) ${ }^{3}$.

International Organizations counts the number of international organizations where

both countries of a dyad are members (Pevehouse et al. 2004). ${ }^{4}$ Alliance is an index of

alliances between an offender and defender. We use Gibler's dataset (2009) to create a weighted sum of alliances between a potential offender and defender, based on Goldsmith et al. (2017). ${ }^{5}$ We also include two control variables to indicate the geographic proximity of two countries in a dyad. Neighboring Country is a dummy variable, coded one if the countries in a dyad share a land border, or if their distance from the sea is less than 24 miles (Stinnet et al. 2002). Capital Distance is a continuous variable based on the geographical distance between capitals (1,000 miles), sourced from Gleditsch (2008).

3 Time span of analysis is different in Goldsmith et al. (2017) and in this article. Their analyses are between 1951 and 2006. Ours are between1816 and 2005. We then do not include a variable on trade interdependence in our main models due to missing values, but we include the trade variable in the robustness check in appendix.

${ }^{4}$ Since Pevehouse et al. (2004) shows the number of international organizations every five years only before 1964, we impute the missing values between the coded years by a value most recently observed. Regarding the most recent four years, we simply impute the values by most recent values available.

${ }^{5}$ Gibler (2009) categorizes alliances into four types: defense pact, neutrality pact, nonaggression pact, and entente. Goldsmith et al. (2017) apply a different weight for each type of alliance. The weight for a defense pact is 1 , the weight for neutrality pact is 0.5 , the weight for non-aggression pact is 0.25 and the weight for an entente pact is 0.125 . 
These four control variables measure the characteristics of dyads.

A further three sets of variables could be used to measure the characteristics of each country, and we include two variables each for a potential offender and a potential defender. Civil Wars is a dummy variable, coded one if at least one civil war occurs in a country in a given year. This variable is based on Sarkees and Wayman (2010). We also use the Composite Index of National Capability (CINC) of the Correlates of War Project to measure the Relative Strength of a country. CINC is a composite index of military expenditure, the number of military personnel, national energy consumption, national steel production, urbanization, and total population; this index becomes larger when a country has more national capacity.

In our models, there is the possibility that we have omitted variables such as prowar sentiment. For example, potential aggression toward neighboring countries may precede the introduction of conscription. In other words, a country that intends to attack other countries may introduce military conscription to prepare for war. This intention may cause a serious endogeneity problem. To take this possibility into consideration, we include the CINC but also the Military Expenditure of offenders and defenders in the 
main model ${ }^{6}$. Controlling for this variable is expected to mitigate the endogeneity problem potentially caused by the correlation between the military recruitment systems and prowar sentiments.

To consider the time dependence of the likelihood of war initiation between two countries, we include Peace Years and its squared and cubic terms (Carter and Signorino 2010). Peace Years measures the number of years since the most current MID from a potential offender to a potential defender before a given year. All key explanatory variables and control variables are lagged by one year.

Table 1 shows the summary statistics of all variables included in our models. MID initiation occurs in $0.2 \%$ of all directed-dyad years. This indicates that MID initiation is a rare event. In terms of our key explanatory variable, the mean value of conscription is 0.57 , which means that more than half of observations adopt conscription. The numbers of observations differ from each variable because of missing values.

6 The correlation between these variables is not so high (0.454) that multicollinearity is strongly suspected. In fact, the regression results do not indicate the presence of multicollinearity. 
Table 1: Summary statistics

\begin{tabular}{llrrrr}
\multicolumn{1}{c}{ Variable } & Obs. & \multicolumn{1}{c}{ Mean } & Std. Dev. & Min. & Max. \\
\hline MID & $1,498,932$ & 0.002 & 0.04 & 0 & 1 \\
Conscription & $1,264,498$ & 0.57 & 0.50 & 0 & 1 \\
Democracy & $1,320,816$ & 0.34 & 0.47 & 0 & 1 \\
International organization & $1,424,800$ & 19.58 & 12.80 & 0 & 108 \\
Alliance & $1,455,992$ & 0.09 & 0.36 & 0 & 5.75 \\
CINC & $1,455,992$ & 0.01 & 0.03 & 0.00 & 0.38 \\
Military expenditure & $1,260,613$ & 11.79 & 2.78 & 2.56 & 19.94 \\
Neighbor country & $1,455,992$ & 0.03 & 0.18 & 0 & 1 \\
Distance & $1,451,990$ & 8.20 & 0.84 & 1.61 & 9.42 \\
Civil war & $1,455,992$ & 0.09 & 0.29 & 0 & 1 \\
Peace years & $1,498,932$ & 28.69 & 29.32 & 0 & 189
\end{tabular}

\subsection{Statistical analysis}

Table 2 shows the main estimation results, while Table 3 displays the average partial

effects (APE) of an offender's adoption of a conscription system, according to the selected models. In Table 2, Model 3 shows our basic results. All the control variables and the interaction between an offender's democracy dummy and a defender's democracy dummy are included in Models 1 and 2. Both the offender's and defender's military expenditures are included in Model 2. The interaction terms between a conscription dummy and a democracy dummy are included in Models 3 and 4. In Model 4, the samples included in 
the analysis are limited to politically relevant countries as a robustness check of the main result7. This Table also displays the Akaike Information Criterion and Bayesian Information Criterion. These criteria imply that the model with the most minimal number among all models is the most appropriate. Therefore, based on the statistics, we prefer Model 3 among Models 1-3.

First, we discuss the validity of our models. We find that almost all the coefficients of control variables are as expected. Model 1 shows that the coefficients of both offender's and defender's conscription are positive and statistically significant without considering military expenditures. This result implies that a country with conscription is more likely to engage in international disputes than one with voluntary recruitment. However, this result may have been obtained due to the endogeneity problem mentioned above. Model 2 shows that including military expenditures in the analysis cancels out the positive effect of conscription completely. Therefore, the coefficients of conscription dummies are not statistically significant in this model, which

7 EUgene (Bennet and Stam 2000) can automatically limit observations by political relevance between countries. Their definition of 'politically relevant' is based on Maoz and Russett (1993). The concepts are defined by the two measures (1) contiguity and (2) major power. 
suggests that the endogeneity problem is drastically mitigated by military expenditures.

Table 2. Main results

\begin{tabular}{|c|c|c|c|c|}
\hline Variables & $\begin{array}{c}\text { Model } 1 \\
\text { Without } \\
\text { Military } \\
\text { Expenditures }\end{array}$ & $\begin{array}{c}\text { Model } 2 \\
\text { With } \\
\text { Military } \\
\text { Expenditures }\end{array}$ & $\begin{array}{c}\text { Model } 3 \\
\text { Conscription* } \\
\text { Democracy }\end{array}$ & $\begin{array}{c}\text { Model } 4 \\
\text { Only } \\
\text { Politically } \\
\text { Relevant }\end{array}$ \\
\hline \multirow[t]{2}{*}{ Democracy (offender) } & 0.119 & 0.064 & $0.486 * * *$ & $0.377^{* *}$ \\
\hline & $(0.061)$ & $(0.064)$ & $(0.102)$ & $(0.116)$ \\
\hline \multirow[t]{2}{*}{ Conscription (offender) } & $0.301 * * *$ & 0.072 & $0.307 * * *$ & $0.368 * * *$ \\
\hline & $(0.052)$ & $(0.057)$ & $(0.074)$ & $(0.084)$ \\
\hline \multirow[t]{2}{*}{ Democracy (defender) } & $0.148^{*}$ & $0.135^{*}$ & $0.650 * * *$ & $0.628 * * *$ \\
\hline & $(0.060)$ & $(0.063)$ & $(0.096)$ & $(0.107)$ \\
\hline \multirow[t]{2}{*}{ Conscription (defender) } & $0.149 * *$ & -0.033 & $0.259 * * *$ & $0.274 * * *$ \\
\hline & $(0.050)$ & $(0.055)$ & $(0.070)$ & $(0.080)$ \\
\hline \multirow[t]{2}{*}{ Democracy*Democracy } & $-1.583^{* * *}$ & $-1.382^{* * *}$ & $-1.416^{* * *}$ & $-1.282^{* * *}$ \\
\hline & $(0.118)$ & $(0.121)$ & $(0.122)$ & $(0.131)$ \\
\hline \multirow[t]{2}{*}{ Democracy*Conscription (offender) } & & & $-0.618 * * *$ & $-0.442 * * *$ \\
\hline & & & $(0.115)$ & $(0.129)$ \\
\hline \multirow[t]{2}{*}{ Democracy*Conscription (defender) } & & & $-0.788 * * *$ & $-0.686^{* * *}$ \\
\hline & & & $(0.110)$ & $(0.122)$ \\
\hline \multirow[t]{2}{*}{ International organizations } & $0.025^{* * *}$ & 0.004 & $0.005^{*}$ & 0.003 \\
\hline & $(0.002)$ & $(0.002)$ & $(0.002)$ & $(0.003)$ \\
\hline \multirow[t]{2}{*}{ Alliance } & $-0.133^{* *}$ & $-0.091^{*}$ & $-0.120 * *$ & $-0.096^{*}$ \\
\hline & $(0.041)$ & $(0.040)$ & $(0.041)$ & $(0.043)$ \\
\hline \multirow[t]{2}{*}{ Relative strength (offender) } & $10.392^{* * *}$ & $7.254 * * *$ & $7.034 * * *$ & $3.926 * * *$ \\
\hline & $(0.342)$ & $(0.489)$ & $(0.494)$ & $(0.524)$ \\
\hline \multirow[t]{2}{*}{ Relative strength (defender) } & $8.229 * * *$ & $7.613^{* * *}$ & $7.294^{* * *}$ & $3.216^{* * *}$ \\
\hline & $(0.391)$ & $(0.521)$ & $(0.530)$ & $(0.568)$ \\
\hline \multirow[t]{2}{*}{ Military expenditure (offender) } & & $0.156^{* * *}$ & $0.153^{* * *}$ & $0.070 * * *$ \\
\hline & & $(0.013)$ & $(0.013)$ & $(0.013)$ \\
\hline \multirow[t]{2}{*}{ Military expenditure (defender) } & & $0.061^{* * *}$ & $0.057 * * *$ & $0.029^{*}$ \\
\hline & & $(0.013)$ & $(0.013)$ & $(0.013)$ \\
\hline \multirow[t]{2}{*}{ Neighboring country } & $1.765^{* * *}$ & $1.717 * * *$ & $1.664^{* * *}$ & $1.115^{* * *}$ \\
\hline & $(0.066)$ & $(0.069)$ & $(0.069)$ & $(0.071)$ \\
\hline \multirow[t]{2}{*}{ Distance } & $-0.532^{* * *}$ & $-0.631^{* * *}$ & $-0.677 * * *$ & $-0.363^{* * *}$ \\
\hline & $(0.024)$ & $(0.026)$ & $(0.027)$ & $(0.031)$ \\
\hline \multirow[t]{2}{*}{ Civil war (offender) } & $0.536^{* * *}$ & $0.502^{* * *}$ & $0.495^{* * *}$ & $0.409 * * *$ \\
\hline & $(0.057)$ & $(0.059)$ & $(0.059)$ & $(0.065)$ \\
\hline \multirow[t]{2}{*}{ Civil war (defender) } & $0.500 * * *$ & $0.517 * * *$ & $0.502^{* * *}$ & $0.399 * * *$ \\
\hline & $(0.059)$ & $(0.061)$ & $(0.061)$ & $(0.067)$ \\
\hline \multirow[t]{2}{*}{ Peace years } & $-0.102^{* * *}$ & $-0.096 * * *$ & $-0.095 * * *$ & $-0.084 * * *$ \\
\hline & $(0.004)$ & $(0.005)$ & $(0.005)$ & $(0.005)$ \\
\hline \multirow[t]{2}{*}{ Peace years (squared) } & $0.002^{* * *}$ & $0.001 * * *$ & $0.001^{* * *}$ & $0.001^{* * *}$ \\
\hline & $(0.000)$ & $(0.000)$ & $(0.000)$ & $(0.000)$ \\
\hline \multirow[t]{2}{*}{ Peace years (cubic) } & $-0.000 * * *$ & $-0.000 * * *$ & $-0.000 * * *$ & $-0.000 * * *$ \\
\hline & $(0.000)$ & $(0.000)$ & $(0.000)$ & $(0.000)$ \\
\hline AIC & 22437.153 & 20223.420 & 20149.002 & 14486.807 \\
\hline BIC & 22637.403 & 20445.184 & 20394.109 & 14691.584 \\
\hline $\mathbf{N}$ & 964,552 & 866,108 & 866,108 & 126,916 \\
\hline
\end{tabular}

Standard errors in parentheses. Constants are not shown. ${ }^{*} p<0.05,{ }^{* *} p<0.01,{ }^{* * *} p<0.001$

AIC=Akaike Information Criterion. BIC=Bayesian Information Criterion 
Table 3. Average partial effects (APE) of a conscription system by an offender on MIDs initiation

\begin{tabular}{|c|c|c|}
\hline \multirow[b]{2}{*}{ Conditional on: } & Model 3 & Model 4 \\
\hline & \multicolumn{2}{|c|}{ APE of conscription on MIDs initiation } \\
\hline \multirow[t]{2}{*}{ Democracy $($ offender $)=1$, Democracy $($ defender $)=1$} & $-0.0002^{* * *}$ & -0.0003 \\
\hline & $(0.0001)$ & $(0.0005)$ \\
\hline \multirow[t]{2}{*}{ Democracy $($ offender $)=1$, Democracy $($ defender $)=0$} & $-0.0008^{* * *}$ & -0.0010 \\
\hline & $(0.0002)$ & $(0.0013)$ \\
\hline \multirow[t]{2}{*}{ Democracy $($ offender $)=0$, Democracy $($ defender $)=1$} & $0.0007 * * *$ & $0.0050 * * *$ \\
\hline & $(0.0002)$ & $(0.0010)$ \\
\hline \multirow[t]{2}{*}{ Democracy $($ offender $)=0$, Democracy $($ defender $)=0$} & $0.0007 * * *$ & $0.0043^{* * *}$ \\
\hline & $(0.0002)$ & (0.0009) \\
\hline
\end{tabular}

Next, we report our main estimation results. We find that in Model 3 both offender's and defender's democracy dummies and conscription dummies, as well as the interaction terms between them, are statistically significant at a level of $1 \%$. Notably, the variables related to conscription dummies are significant in this model. This result is clearly different from those shown in Model 2, even after controlling for military expenditures, perhaps because the misspecification is solved after including the interaction terms. This result is consistent with our hypotheses.

Figure 1 graphically describes our main estimation results, focusing on a conscription dummy. The upper two figures show the change in predicted probabilities 
of initiating conflicts when an offender is autocratic, according to the defender's regime type. Similarly, the bottom two figures reveal the change in predicted probabilities of initiating conflicts when an offender is democratic, according to the defender's regime type.

The upper part of Figure 1 suggests that if an autocratic country introduces a conscription system, this country is likely to initiate conflicts regardless of the potential defender's regime type. In both cases, the APE of adopting a conscription system is approximately $0.07 \%$.

Furthermore, the lower parts of Figure 1 indicate that if a democratic country adopts conscription, this country is not likely to initiate conflicts regardless of the potential defender's regime type. In contrast to the results shown where an offender is autocratic, the APE of conscription are different when a potential defender's regime type is considered. If the potential defender is autocratic, then the APE is 0.08\%; otherwise the APE is $-0.02 \%$.

Why is the APE of an offender's adoption of conscription lower in the democratic-democratic case? One interpretation is that this result reflects DP at the 
dyadic level. The right-side of the lower part of Figure 1 shows that the probability of initiating conflicts in the case of democratic-democratic offenders and defenders with voluntary recruitment is around $0.01 \%$, which is the lowest probability, compared with the probabilities of other cases. Therefore, there is little room to reduce the probability by adopting conscription in the democratic-democratic case.

Figure 1 also implies that the difference in the predicted probabilities is affected by an offender's regime type. We find that the probability is higher when an offender is democratic. However, the theory suggests that a democratic country should be less likely to initiate conflict than an autocratic country. One possible reason for such a counterintuitive result is that the impacts of regime types and recruiting types vary among time periods, as argued by Nieman (2016). Therefore, we conduct an additional analysis, applying our model to (1) the whole period, (2) the period before World War II, (3) the Cold War, and 4) post-1989. 


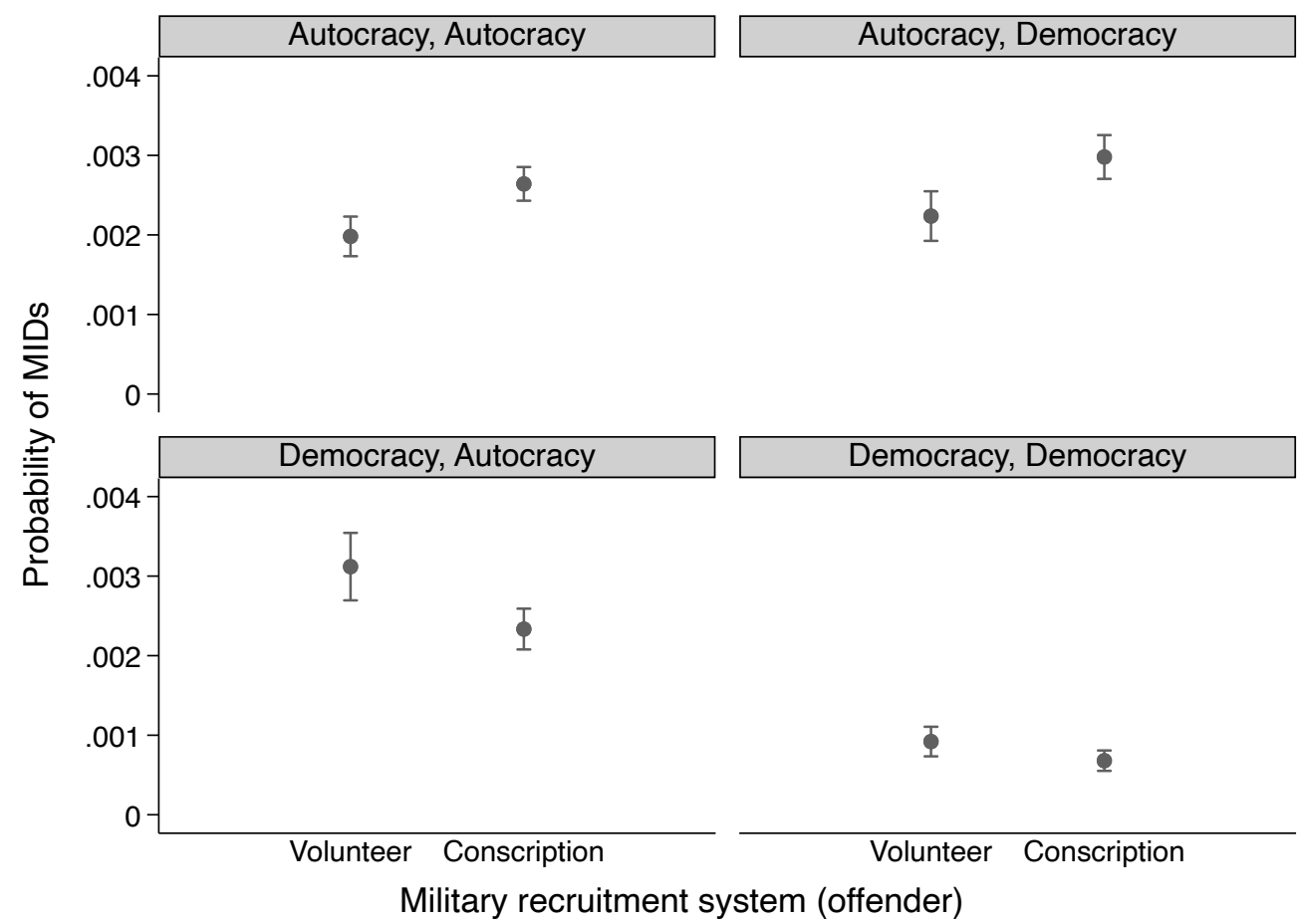

Figure 1 Predicted probabilities of MIDs initiation

Table 4 summarizes our additional estimation results. We find that the effects

of our interest variables vary among the time periods. Firstly, the offender's democracy dummy is not statistically significant in Models 4 and 6, while it is positive and statistically significant in Model 5. This result indicates that a democratic regime has a positive impact on the probability of initiating conflicts only during the period of 19461989; this was the Cold War period. We could say that, in this period, the citizens of democratic countries may have been more martial compared with democratic citizens in other periods. On the other hand, the interaction terms between offender's and 
defender's democracy dummies are statistically significant in all models. We confirm that DP at the dyadic level is valid in all periods. Moreover, the offender's democracy and conscription dummies and the interaction terms between an offender's democracy dummy and an offender's conscription dummy have no statistical impact on MIDs in Model 6 (1990-2005). One reason for this may simply be that fewer wars occurred in this period as compared with other periods. However, this does not appear to be the real reason because MID cases occurred at about the same level during two other periods 1946-1989 (0.16\%) and 1990-2005 (0.11\%).

Table 4. Additional results

\begin{tabular}{lccc}
\multicolumn{1}{c}{ Variables } & $\begin{array}{c}\text { Model 4 } \\
(1817-1945)\end{array}$ & $\begin{array}{c}\text { Model 5 } \\
(1946-1989)\end{array}$ & $\begin{array}{c}\text { Model 6 } \\
(1990-2005)\end{array}$ \\
\hline Democracy (offender) & -0.049 & $0.615^{* * *}$ & 0.229 \\
Conscription (offender) & $(0.270)$ & $(0.157)$ & $(0.172)$ \\
& $0.657^{* *}$ & $0.394^{* * *}$ & -0.216 \\
Democracy*Democracy & $(0.230)$ & $(0.105)$ & $(0.130)$ \\
& $-0.568^{*}$ & $-1.501^{* * *}$ & $-1.254^{* * *}$ \\
Democracy*Conscription (offender) & $-0.847^{* *}$ & $-0.527^{* *}$ & -0.359 \\
& $(0.297)$ & $(0.178)$ & $(0.199)$ \\
\hline Defender side variables & $\mathrm{Y}$ & $\mathrm{Y}$ & $\mathrm{Y}$ \\
Control variables & $\mathrm{Y}$ & $\mathrm{Y}$ & $\mathrm{Y}$ \\
N & 66,182 & 451,452 & 348,474 \\
\hline
\end{tabular}

Standard errors in parentheses. Constants are not shown.

${ }^{*} \mathrm{p}<0.05,{ }^{* *} \mathrm{p}<0.01,{ }^{* * *} \mathrm{p}<0.001$ 
We infer from this result that, prior to 1990 and especially before WW II, battles were fought with low-tech weapons. Soldiers had to endure the horrors of trench warfare. In contrast, the way in which battles are carried out in the present day is drastically different. There is less battlefield engagement, even when there is a conscripted army. Warfare has more to do with launching missiles, and conscripted soldiers do not necessarily have to fight face-to-face. This change in the way in which warfare occurs may decrease the fear people feel toward interstate conflict. Technological advances in warfare may explain the differences of the effect of conscription on a country's military aggressiveness between the past and the present ${ }^{8}$.

8 Walsh and Schulzke (2018) suggests the possibility that the way to fight can affect the people's support for wars. 


\section{Conclusion}

A large number of international relations researchers have explored the causes of war. A major line of research pays special attention to political regimes and considers democracy to be a key determinant of peace. However, the literature tends to overlook other domestic political factors such as the type of military recruitment.

This paper attempts to fill the gap in the literature by analyzing the effect of political regimes and military recruitment type on international conflicts. This study hypothesizes that democratic countries with conscription tend to engage in conflict against neighboring countries less than those with voluntary recruitment. Moreover, it also hypothesizes that authoritarian countries with conscription tend to engage in conflicts against neighboring countries more than those with voluntary armies. This is because people in democratic countries who are unwilling to go to war have greater influence over their leaders through elections, while people in authoritarian countries do not have that same influence.

The results of this study reveal that our hypotheses are statistically supported. The results also suggest that technological change may need to be taken into 
consideration. In the past, the effect of conscription and democracy on international conflicts was found as we hypothesized. However, there are differences seen in recent years. This may be due to innovations in weaponry and new ways in which international conflict occurs. This implies that the introduction of conscription systems in democratic countries may not lead to the same unwillingness to engage in war today as it did in the past. The effect of conscription on people's attitudes toward conflict may not only be conditioned by political regime but also by military technology. We should take all of these factors into consideration when deciding which type of military recruitment is optimum for maintaining peace.

We are confident on our analyses and results, however, there are several limitations. First, to address the endogeneity problem caused by country's combativeness, it may be necessary to use some instrumental variables approach. In this paper, the possibility of the problem may be not completely denied, though mitigated to a great extent. Second, we imply that the technological change may affect the interaction effect of political regime and military recruitment on international disputes. However, we cannot operationalize a variable to reflect the change and explore the relationship in the analyses directly. These issues still remain for the future research. 


\section{References}

Barbieri, Katherine, Omar M. G. Keshk, and Brian Pollins (2009) "TRADING DATA: Evaluating our Assumptions and Coding Rules." Conflict Management and Peace Science 26: 471-491.

Beck, Nathaniel, Jonathan N. Katz and Richard Tucker (1998) "Taking Time Seriously: Time-Series-Cross-Section Analysis with a Binary Dependent Variable." American Journal of Political Science 42: 1260-1288.

Bennett, D. Scott, and Allan Stam (2000) "EUGene: A Conceptual Manual." International Interactions 26: 179-204.

Benoit, Kenneth (1998) "Democracies Really Are More Pacific (in General): Reexamining Regime Type and War Involvement." Journal of Conflict Resolution 40: 636-657.

Bremer, Stuart A. (1992) "Dangerous Dyads: Conditions Affecting the Likelihood of Interstate War, 1816-1965.” Journal of Conflict Resolution 36: 309-341.

Bremer, Stuart A. (1993) "Democracy and militarized interstate conflict, 1816-1965." International Interactions 18: 231-249.

Bueno de Mesquita, Bruce, James D. Morrow, Randolph M. Siverson, and Alastair Smith (1999) “An Institutional Explanation of the Democratic Peace.” American Political Science Review 93: 791-807.

Carter, David B., and Curtis S. Signorino (2010) "Back to the Future: Modeling Time Dependence in Binary Data." Political Analysis 18: 271-292.

Choi, Seung-Whan and Patrick James (2003) "No Professional Soldiers, No Militarized Interstate Disputes?" Journal of Conflict Resolution 47: 796-816.

Choi, Seung-Whan and Patrick James (2008) "Civil-Military Structure, Political Communication, and the Democratic Peace.” Journal of Peace Research 45: 37-3.

Correlates of War Project (2017) "State System Membership List, v2016." available at http://correlatesofwar.org

Dafoe, Allan (2011) "Statistical Critiques of the Democratic Peace: Caveat Emptor." American Journal of Political Science 55: 247-262. 
Doyle, Michael (1983a) "Kant, Liberal Legacies, and Foreign Affairs: Part I." Philosophy and Public Affairs 12: 205-235.

Doyle, Michael (1983b) “Kant, Liberal Legacies, and Foreign Affairs: Part II.” Philosophy and Public Affairs 12: 323-353

Doyle, Michael (1986) "Liberalism and World Politics." American Political Science Review 80:1151-1169.

Enterline, Andrew J., (1998) "Regime Changes, Neighborhoods, and Interstate Conflict, 1816-1992." Journal of Conflict Resolution 42: 804-829.

Fearon, James (1994) "Domestic Political Audiences and the Escalation of International Disputes." American Political Science Review 88: 577-592.

Gartzke, Erik (1998) "Kant We All Just Get Along? Opportunity, Willingness, and the Origins of the Democratic Peace." American Journal of Political Science 42: 1-27.

Gartzke, Erik (2000) "Preferences and the Democratic Peace." International Studies Quarterly 44:191-210.

Gibler, Douglas M. (2009) International Military Alliances, 1648-2008. CQ Press.

Gleditsch, Kristian S. (2002) "Expanded Trade and GDP Data." Journal of Conflict Resolution 46: 712-724.

Gleditsch, Kristian S. (2008) "Distance between Capital Cities." University of Essex. available at http://privatewww. essex. ac. uk/ ksg/data-5. html.

Goldsmith, Benjamin E., Dimitri Semenovich, Arcot Sowmya, and Gorana Grgic (2017) "Political Competition and the Initiation of International Conflict: A New Perspective on the Institutional Foundations of Democratic Peace." World Politics 69: 493-531.

Hensel, Paul R., Gary Goertz, and Paul F. Diehl (2000) "The Democratic Peace and Rivalries." The Journal of Politics 62: 1173-1188.

Horowitz, Michael C. and Matthew S. Levendusky (2011) "Drafting Support for War: Conscription and Mass Support for Warfare." The Journal of Politics 73: 524-534. 
Horowitz, Michael C., Erin M. Simpson, and Allan C. Stam (2011) "Domestic Institutions and Wartime Casualties.” International Studies Quarterly 55: 909-936.

Johns, Robert, and Graeme A. M. Davies (2012) "Democratic Peace or Clash of Civilizations? Target States and Support for War in Britain and the United States." The Journal of Politics 74: 1038-52.

Jones, Daniel M., Stuart A. Bremer, and J. David Singer (1996) "Militarized Interstate Disputes, 1816-1992: Rationale, Coding Rules, and Empirical Patterns." Conflict Management and Peace Science 15: 163-213.

Kant, Immanuel. [1795] (1970) "Perpetual Peace: A Philosophical Sketch." In Kant's Political Writings, ed. Hans Reiss, trans. H. B. Nisbet. Cambridge: Cambridge University Press. pp. 93-130.

Kriner, Douglas L. and Francis X. Shen (2016) "Conscription, Inequality, and Partisan Support for War." Journal of Conflict Resolution 60: 1419-1445.

Mansfield, Edward D., and Jack Snyder (1995) "Democratization and the Danger of War." International Security 20: 5-38.

Mansfield, Edward D., and Jack Snyder (2002) "Democratic Transitions, Institutional Strength, and War.” International Organization 56: 297-337.

Marshall, Monty G., and Keith Jaggers (2002). Polity IV Project: Political Regime Characteristics and Transitions, 1800-2002.

Maoz, Zeev, and Nasrin Abdolali (1989) "Polity Types and International Conflict." Journal of Conflict Resolution 33: 3-35.

Maoz, Zeev, and Bruce Russett (1993) "Normative and Structural Causes of Democratic Peace, 1946- 1986." American Political Science Review 87: 624-638.

Maoz, Zeev, Paul L. Johnson, Jasper Kaplan, Fiona Ogunkoya, and Aaron Shreve (2019) "The Dyadic Militarized Interstate Disputes (MIDs) Dataset Version 3.0: Logic, Characteristics, and Comparisons to Alternative Datasets." Journal of Conflict Resolution 63: 811-835. 
Nieman, Mark D. (2016). "Moments in Time: Temporal Patterns in the Effect of Democracy and Trade on Conflict." Conflict Management and Peace Science 33: 273293.

Oneal, John R. and Bruce Russett (1999) "The Kantian Peace: The Pacific Benefits of Democracy, Interdependence, and Inter-national Organizations, 1885-1992." World Politics 52: 1-37.

Oneal, John R., Bruce Russett, and Michael L. Berbaum (2003) "Causes of Peace: Democracy, Interdependence, and International Organizations, 1885-1992." International Studies Quarterly 47:371-393.

Pevehouse, Jon C., Timothy Nordstrom, and Kevin Warnke (2004) "The COW-2 International Organizations Dataset Version 2.0.” Conflict Management and Peace Science 21: 101-119.

Pickering, Jeffrey (2011) "Dangerous Drafts? A Time-Series, Cross-National Analysis of Conscription and the Use of Military Force, 1946-2001." Armed Forces \& Society 37: 119-140.

Ray, James L. (1998) “Does Democracy Cause Peace?” Annual Review of Political Science $1: 27-46$.

Reiter, Dan, and Allan C. Stam (2003) "Identifying the Culprit: Democracy, Dictatorship, and Dispute Initiation." American Political Science Review 97: 333-337.

Rousseau, David L., Christopher Gelpi, Dan Reiter, and Paul K. Huth (1996) "Assessing the Dyadic Nature of the Democratic Peace, 1918-1988." American Political Science Review 90:512-533.

Rummel, Rudolph J. (1995) "Democracies are Less Warlike Than Other Regimes." European Journal of International Relations 1:457-479.

Sarkees, Meredith Reid and Frank Wayman (2010) Resort to War: 1816-2007. Washington DC: CQ Press.

Schultz, Kenneth A. (2001) Democracy and Coercive Diplomacy. New Jersey: Princeton University. 
Stinnett, Douglas M., Jaroslav Tir, Philip Schafer, Paul F. Diehl, and Charles Gochman (2002) “The Correlates of War Project Direct Contiguity Data, Version 3." Conflict Management and Peace Science 19: 58-66.

Tomz, Michael R. and Jessica L. Weeks (2013) "Public Opinion and the Democratic Peace." American Political Science Review 107: 849-865.

Toronto, Nathan (2014) "Military Recruitment Data Set, Version 2014." available at https://nathantoronto.com/research.

Vasquez, Joseph P. (2005) "Shouldering the Soldiering: Democracy, Conscription, and Military Casualties." Journal of Conflict Resolution 49:849-873.

Walsh, James I., Marcus Schulzke (2018) Drones and Support for the Use of Force. Ann Arbor: University Michigan Press.

Ward, Michael D., and Kristian S. Gleditsch (1998) "Democratizing for Peace." American Political Science Review 92: 51-61.

World Bank (2018) World Development Indicators. available at http://data.worldba nk.org/data-catalog/world-development-indicators 


\section{Appendix}

In this appendix, we carry out additional analyses as a robustness check of our main results. Table A1 shows the results of the models including Trade Dependence as a control variable. The variable is obtained from World Bank 2018, Gleditsch (2002) and Barieri et al. (2009). This variable measures how a potential offender depends on a potential defender in terms of trade, and is a percentage of imports to and exports from a defender per GDP of an offender (natural logarithmic form). Goldsmith et al. (2017) includes Trade Dependence in their models, but they restrict the analysis period because of this variable. These results are not much different from our main results. 
Table A1. Main results

\begin{tabular}{|c|c|c|c|c|}
\hline $\begin{array}{r}\text { Variables } \\
\end{array}$ & $\begin{array}{c}\text { Model } 1 \\
\text { Without } \\
\text { Military } \\
\text { Expenditures }\end{array}$ & $\begin{array}{c}\text { Model } 2 \\
\text { With } \\
\text { Military } \\
\text { Expenditures }\end{array}$ & $\begin{array}{c}\text { Model } 3 \\
\text { Conscription* } \\
\text { Democracy }\end{array}$ & $\begin{array}{c}\text { Model } 4 \\
\text { Only } \\
\text { Politically } \\
\text { Relevant } \\
\end{array}$ \\
\hline Democracy (offender) & $\begin{array}{l}-0.092 \\
(0.063)\end{array}$ & $\begin{array}{l}-0.128 \\
(0.067)\end{array}$ & $\begin{array}{c}0.181 \\
(0.104)\end{array}$ & $\begin{array}{l}0.275^{*} \\
(0.119)\end{array}$ \\
\hline Conscription (offender) & $\begin{array}{c}0.156^{* *} \\
(0.053)\end{array}$ & $\begin{array}{l}-0.017 \\
(0.057)\end{array}$ & $\begin{array}{l}0.157^{*} \\
(0.075)\end{array}$ & $\begin{array}{c}0.297^{* * *} \\
(0.086)\end{array}$ \\
\hline Democracy (defender) & $\begin{array}{l}-0.072 \\
(0.062)\end{array}$ & $\begin{array}{l}-0.056 \\
(0.065)\end{array}$ & $\begin{array}{c}0.372^{* * *} \\
(0.098)\end{array}$ & $\begin{array}{c}0.512^{* * * *} \\
(0.110)\end{array}$ \\
\hline Conscription (defender) & $\begin{array}{c}0.021 \\
(0.052)\end{array}$ & $\begin{array}{l}-0.100 \\
(0.056)\end{array}$ & $\begin{array}{l}0.145^{*} \\
(0.072)\end{array}$ & $\begin{array}{c}0.216^{* *} \\
(0.082)\end{array}$ \\
\hline Democracy*Democracy & $\begin{array}{c}-1.562^{* * * *} \\
(0.120)\end{array}$ & $\begin{array}{c}-1.383^{* * * *} \\
(0.124)\end{array}$ & $\begin{array}{c}-1.405^{* * * *} \\
(0.124)\end{array}$ & $\begin{array}{c}-1.277^{* * * *} \\
(0.133)\end{array}$ \\
\hline Democracy*Conscription (offender) & & & $\begin{array}{c}-0.450 * * * * \\
(0.117)\end{array}$ & $\begin{array}{c}-0.390^{* *} \\
(0.131)\end{array}$ \\
\hline Democracy*Conscription (defender) & & & $\begin{array}{c}-0.648^{* * *} \\
(0.112)\end{array}$ & $\begin{array}{c}-0.644^{* * *} \\
(0.125)\end{array}$ \\
\hline International organizations & $\begin{array}{c}0.024^{* * *} \\
(0.002)\end{array}$ & $\begin{array}{l}0.005^{*} \\
(0.002)\end{array}$ & $\begin{array}{l}0.006^{*} \\
(0.002)\end{array}$ & $\begin{array}{c}0.004 \\
(0.003)\end{array}$ \\
\hline Alliance & $\begin{array}{c}-0.157 * * * \\
(0.040)\end{array}$ & $\begin{array}{l}-0.128^{* *} \\
(0.040)\end{array}$ & $\begin{array}{c}-0.146^{* * *} \\
(0.040)\end{array}$ & $\begin{array}{l}-0.104^{*} \\
(0.043)\end{array}$ \\
\hline Trade dependence & $\begin{array}{c}0.190 * * * \\
(0.010)\end{array}$ & $\begin{array}{c}0.179 * * * \\
(0.011)\end{array}$ & $\begin{array}{c}0.170 * * * \\
(0.011)\end{array}$ & $\begin{array}{c}0.068^{* * * *} \\
(0.013)\end{array}$ \\
\hline Relative strength (offender) & $\begin{array}{c}6.817 * * * \\
(0.393)\end{array}$ & $\begin{array}{l}4.164^{* * * *} \\
(0.535)\end{array}$ & $\begin{array}{l}4.073^{* * *} \\
(0.540)\end{array}$ & $\begin{array}{c}3.182^{* * * *} \\
(0.561)\end{array}$ \\
\hline Relative strength (defender) & $\begin{array}{c}4.566^{* * *} \\
(0.439)\end{array}$ & $\begin{array}{c}4.575^{* * * *} \\
(0.561)\end{array}$ & $\begin{array}{c}4.405^{* * *} \\
(0.570)\end{array}$ & $\begin{array}{c}2.278^{* * * *} \\
(0.605)\end{array}$ \\
\hline Military expenditure (offender) & & $\begin{array}{c}0.143^{* * * *} \\
(0.013)\end{array}$ & $\begin{array}{c}0.142^{* * * *} \\
(0.013)\end{array}$ & $\begin{array}{c}0.069 * * * \\
(0.014)\end{array}$ \\
\hline Military expenditure (defender) & & $\begin{array}{c}0.039 * * * \\
(0.013)\end{array}$ & $\begin{array}{c}0.036^{* * *} \\
(0.013)\end{array}$ & $\begin{array}{l}0.028^{*} \\
(0.014)\end{array}$ \\
\hline Neighboring country & $\begin{array}{c}1.413^{* * * *} \\
(0.066)\end{array}$ & $\begin{array}{c}1.425^{* * * *} \\
(0.070)\end{array}$ & $\begin{array}{c}1.403^{* * *} \\
(0.069)\end{array}$ & $\begin{array}{c}1.053^{* * *} \\
(0.072)\end{array}$ \\
\hline Distance & $\begin{array}{c}-0.435^{* * *} \\
(0.026)\end{array}$ & $\begin{array}{c}-0.540 * * * \\
(0.028)\end{array}$ & $\begin{array}{c}-0.575^{* * *} \\
(0.028)\end{array}$ & $\begin{array}{c}-0.346^{* * *} \\
(0.031)\end{array}$ \\
\hline Civil war (offender) & $\begin{array}{c}0.586^{* * *} \\
(0.058)\end{array}$ & $\begin{array}{c}0.550^{* * * *} \\
(0.060)\end{array}$ & $\begin{array}{c}0.548^{* * * *} \\
(0.060)\end{array}$ & $\begin{array}{c}0.424^{* * * *} \\
(0.066)\end{array}$ \\
\hline Civil war (defender) & $\begin{array}{c}0.531 * * * \\
(0.060)\end{array}$ & $\begin{array}{c}0.557 * * * \\
(0.063)\end{array}$ & $\begin{array}{c}0.545^{* * * *} \\
(0.063)\end{array}$ & $\begin{array}{c}0.419^{* * * *} \\
(0.069)\end{array}$ \\
\hline Peace years & $\begin{array}{c}-0.101^{* * *} \\
(0.004)\end{array}$ & $\begin{array}{c}-0.096^{* * *} \\
(0.005)\end{array}$ & $\begin{array}{c}-0.095^{* * *} \\
(0.005)\end{array}$ & $\begin{array}{c}-0.084^{* * * *} \\
(0.005)\end{array}$ \\
\hline Peace years (squared) & $\begin{array}{c}0.001^{* * * *} \\
(0.000)\end{array}$ & $\begin{array}{c}0.001^{* * * *} \\
(0.000)\end{array}$ & $\begin{array}{c}0.001^{* * *} \\
(0.000)\end{array}$ & $\begin{array}{c}0.001^{* * *} \\
(0.000)\end{array}$ \\
\hline Peace years (cubic) & $\begin{array}{c}-0.000 * * * \\
(0.000)\end{array}$ & $\begin{array}{c}-0.000 * * * \\
(0.000)\end{array}$ & $\begin{array}{c}-0.000 * * * \\
(0.000)\end{array}$ & $\begin{array}{c}-0.000 * * * \\
(0.000)\end{array}$ \\
\hline AIC & 21256.183 & 19272.682 & 19229.840 & 14111.349 \\
\hline BIC & 21466.648 & 19504.615 & 19484.966 & 14325.674 \\
\hline $\mathrm{N}$ & 884,270 & 803,452 & 803,452 & 125,752 \\
\hline
\end{tabular}

Standard errors in parentheses. Constants are not shown. ${ }^{*} p<0.05,{ }^{* *} p<0.01,{ }^{* * *} p<0.001$

$\mathrm{AIC}=$ Akaike Information Criterion. BIC=Bayesian Information Criterion 